Research Article

\title{
Morphology and Electrochemical Characterization of Electrodeposited Nanocrystalline Ni-Co Electrodes for Methanol Fuel Cells
}

\author{
R. Abdel-Karim (D, M. Ramadan, and S. M. El-Raghy \\ Corrosion and Surface Treatment Laboratory, Department of Metallurgy, Faculty of Engineering, Cairo University, Giza, Egypt \\ Correspondence should be addressed to R. Abdel-Karim; randaabdelkarim@gmail.com
}

Received 31 October 2017; Revised 14 June 2018; Accepted 8 July 2018; Published 7 August 2018

Academic Editor: Paulo Cesar Morais

Copyright $\odot 2018$ R. Abdel-Karim et al. This is an open access article distributed under the Creative Commons Attribution License, which permits unrestricted use, distribution, and reproduction in any medium, provided the original work is properly cited.

\begin{abstract}
An electrocatalytic electrode surface was developed for alcoholic fuel cell by electrodeposition of Ni-Co alloy on a 301 stainless steel substrate. Material characterization by EDX and XRD confirmed deposition of Ni-Co alloy on stainless steel surfaces with a cobalt content of 15-35\%. SEM showed nodular and/or angular particles with some subparticles embedded within the coarse nodules. Increasing the deposition current density as well as deposition time leads to deposition of Ni-Co alloys characterized by coarse angular morphology with lower cobalt content. The electrocatalytic activity of the coated electrodes was characterized by potentiodynamic polarization test, electrochemical impedance spectroscopy (EIS), and cyclic voltammetry (CV) tests in anodic solution for electrochemical oxidation of methanol. Polarization study showed very much higher current density for the coated electrode compared to bare stainless steel. According to the EIS test in $1 \mathrm{M}$ methyl alcohol acidic solution, it was found that polarization resistance of the coated sample was much lower compared to the bare substrate. The electrical equivalent circuit at the metal solution interface was found to be matching Randle with Warburg resistance. The results of the CV test showed higher peaks for alcohol oxidation and oxygen reduction compared to the bare substrate. The alloy coating with increased effective surface area leads to enhancement in the electrocatalytic activity of the electrodes. The alloys deposited at current densities of 50 and $80 \mathrm{~mA} / \mathrm{cm}^{2}$ for 30 minutes $(15-16 \%$ Co) had higher catalytic activity of the Ni-Co nanocrystalline deposits for methanol oxidation for direct methanol fuel cells, than those under other deposition conditions.
\end{abstract}

\section{Introduction}

Nowadays, a higher demand for energy is observed [1]. Fuel cells can be considered as a main partner in stationary, transporting, and portable energy sectors [2-6]. Extensive researches were directed to study direct methanol fuel cells due to the easy fuel production from the biomass. Synthesizing fuels from the biomass will be useful for clean energy production to meet the global growing demand of pollution-free renewable energy $[7,8]$. In direct methanol fuel cells, fuel is converted electrochemically to electricity avoiding the limitation of the Carnot cycle which limits high-efficiency energy conversion $[9,10]$. Woody biomass which is generated from agriculture wastes can be converted to ethanol or ethanol by hydrolysis and subsequent fermentation by microorganisms [11-13]. As the fuel in the fuel cells is oxidized at the anode and the output current is delivered at the cathode, the material and the surface properties of the anode are very important. The main problem here is the polarization of the anode and the cathode which leads to minimization of the output current $[14,15]$. For the anode materials, this problem can be solved by using a material of higher electrocatalytic behavior with good electrical conductivity, low polarization resistance, strong biocompatibility, chemical stability, corrosion resistance, good strength, and higher toughness. From the beginning of fuel cell production, the carbon and metallic materials are usually used as the anode due to their excellent properties such as chemical stability, higher electrical conductivity, and lower weight.

Pt can be considered as an excellent catalyst for dehydrogenation. The main problems of Pt catalysts are the poisoning by halides and $\mathrm{CO}$, which is produced as a by-product 
TABLE 1: The steel substrate chemical composition.

\begin{tabular}{lccccccccc}
\hline Element & $\mathrm{C}$ & $\mathrm{N}$ & $\mathrm{Si}$ & $\mathrm{V}$ & $\mathrm{Cr}$ & $\mathrm{Mn}$ & $\mathrm{Co}$ & $\mathrm{Ni}$ & $\mathrm{Fe}$ \\
\hline $\mathrm{wt} \%$ & 0.0471 & 0.11 & 0.643 & 0.142 & 18.6 & 1.32 & 0.173 & 7.32 & Rem. \\
\hline
\end{tabular}

of the used alcohol oxidation, and high cost [16]. Much effort was done to promote $\mathrm{CO}$ oxidation and increase the electrocatalysis by alloying some metals such as $\mathrm{Os}, \mathrm{Sn}, \mathrm{Au}, \mathrm{W}, \mathrm{Pd}$, $\mathrm{Ru}, \mathrm{Rh}, \mathrm{Pb}, \mathrm{Ir}$, and $\mathrm{Bi}$, to Pt. Platinum-based nanomaterial can achieve a higher surface area with higher active site number. An increase in the active site number leads to an increase in the electrocatalytic behavior of the catalyst towards methanol oxidation and hence an increase in the overall performance of fuel cells $[17,18]$.

Nonplatinum electrocatalysts can be used as an excellent alternative for platinum and platinum-based electrocatalysts. This is due to their lower cost and excellent performance. There is limited research on using Ni-based nonplatinum electrocatalysts containing other elements such as $\mathrm{Al}, \mathrm{Pd}$, Sn, and Fe. According to Mohamedi et al. [19], a small addition of Al to Ni produces excellent electrodes in molten carbonate fuel cells. Kumar et al. [20] stated that there is a wide range of composition of Ni-Pd electrodes which used as anode material in methanol oxidative fuel cells in the alkaline medium. Some research studies have discussed the electrocatalytic behavior of nanocrystalline $\mathrm{Ni}$-Co electrodeposits [21-24].

Electrodeposition has a lot of advantages over other surface modification techniques such as low cost and capability of manufacturing multicomponent nanocrystalline materials for many energy applications [25-28].

In this work, attempts have been made to manufacture $\mathrm{Ni}$-Co electrodes for direct methanol fuel cells on stainless steel substrates by electrodeposition. Electrochemical characterization of these electrodes was made by potentiodynamic polarization test, electrochemical impedance spectroscopy (EIS) test, and cyclic voltammetry (CV) test. The surface morphology and the structural characterization of the deposited electrodes were investigated using scanning electron microscopy (SEM) and X-ray diffraction (XRD), respectively. The elemental composition of the deposited electrodes was performed by energy-dispersive X-ray (EDX).

\section{Experimental Methods}

2.1. Testing Material and Pretreatment. The substrate used in the electrodeposition process was 301 stainless steel, delivered in the form of $0.4 \mathrm{~mm}$ thick polished sheet for having the chemical analysis as shown in Table 1. The specimens were machined to be $4 \mathrm{~cm}$ long and $1.5 \mathrm{~cm}$ wide. Before electrodeposition, all samples were subjected to electrolytic activation pretreatment in a solution of $60 \% \mathrm{H}_{2} \mathrm{SO}_{4}$ (wt. percent) at a temperature of $80^{\circ} \mathrm{C}$. This was followed by rinsing distilled water in order to remove any traces of chemicals.

2.2. Electrodeposition. The electrodeposition cell was composed of a disc-shaped nickel anode and a rectangular stainless steel cathode which were connected to the positive and
TABLE 2: Chemical analysis of electrolytic bath and controlling parameters for electrodeposition of Ni-Co.

\begin{tabular}{|c|c|}
\hline Const. bath components and parameters & Concentration in $(\mathrm{g} / \mathrm{L})$ \\
\hline $\mathrm{NiSO}_{4} \cdot 7 \mathrm{H}_{2} \mathrm{O}$ & 177 \\
\hline $\mathrm{NiCL}_{2} \cdot 7 \mathrm{H}_{2} \mathrm{O}$ & 32 \\
\hline $\mathrm{CoSO}_{4} \cdot 7 \mathrm{H}_{2} \mathrm{O}$ & 11 \\
\hline $\mathrm{HCHO}$ & 25 \\
\hline $\mathrm{HCOOH}$ & 23 \\
\hline $\mathrm{H}_{3} \mathrm{BO}_{3}$ & 30 \\
\hline Current density $\left(\mathrm{mA} / \mathrm{cm}^{2}\right)$ & $30,50,80$ \\
\hline Deposition time (min) & $15,20,30$ \\
\hline $\mathrm{pH}$ & $2.5-3$ \\
\hline Temperature & $21 \pm 1^{\circ} \mathrm{C}$ \\
\hline
\end{tabular}

negative poles of a Chroma 62000P-100-25-type DC power supply with a Chroma 62000P software. The two electrodes were immersed in an electrolyte containing $\mathrm{Ni}$ and Co salts in addition to some additives, as illustrated in Table 2. All of the bath parameters such as $\mathrm{pH}$, temperature, deposition current density, and deposition time are indicated in Table 2.

2.3. XRD Analysis. The type of phases formed in different electrodeposited samples was determined by XRD. The phases contained in the nanocrystalline $\mathrm{Ni}$-Co alloys were examined by an X-ray diffraction unit (X'Pert PRO PANanalytical) with a copper anode $\left(k_{\alpha}=1.540598 \AA\right)$ and using an applied voltage of $45 \mathrm{kV}$. Data of XRD were based on Bragg's equation. The crystalline diameter was estimated by Scherrer's equation using the peak broadening of the most intense peak.

2.4. SEM and EDX. The SEM (model Quanta 250 FEG (field emission gun) attached with EDX unit (energy dispersive Xray analyses), with accelerating voltage $30 \mathrm{KV}$, magnification $14 \mathrm{x}$ up to $1,000,000 \mathrm{x}$ and resolution for Gun.1n, was used to examine the microstructure and presented morphology while EDX was used to identify the chemical composition.

2.5. Potentiodynamic Polarization. The solution used to characterize the electrocatalytic activity towards methanol oxidation was $1 \mathrm{M}$ methanol $+0.5 \mathrm{M} \mathrm{H}_{2} \mathrm{SO}_{4}$. The test was performed at room temperature. Electrochemical measurements were conducted using a VoltaLab 10 potentiostat coupled with PGZ 100 analyst software, controlled by a personal computer in conventional three-electrode-cell systems. The working electrode was the steel substrate or Ni-Co-coated electrode, the auxiliary electrode was the Pt electrode, and the reference electrode was the saturated calomel electrode 


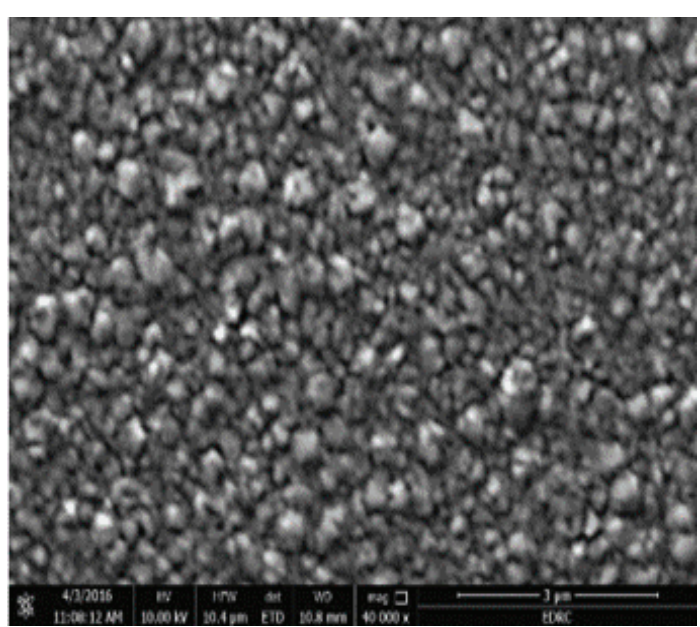

(a)

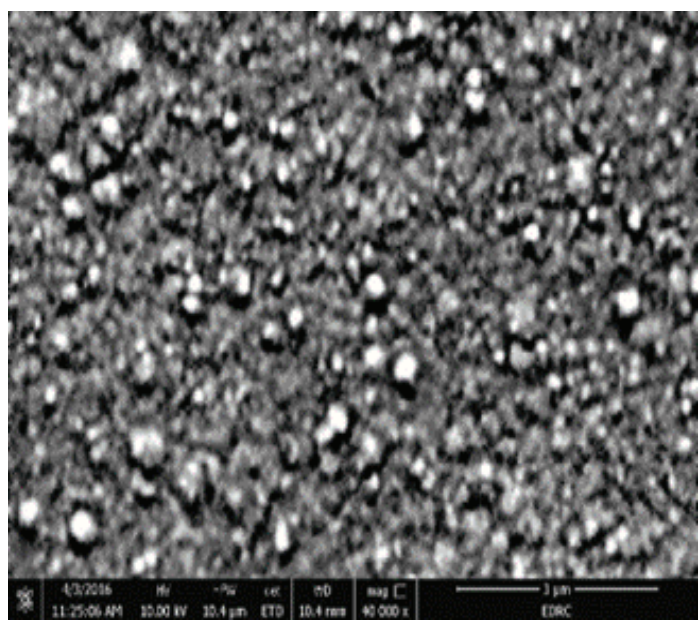

(b)

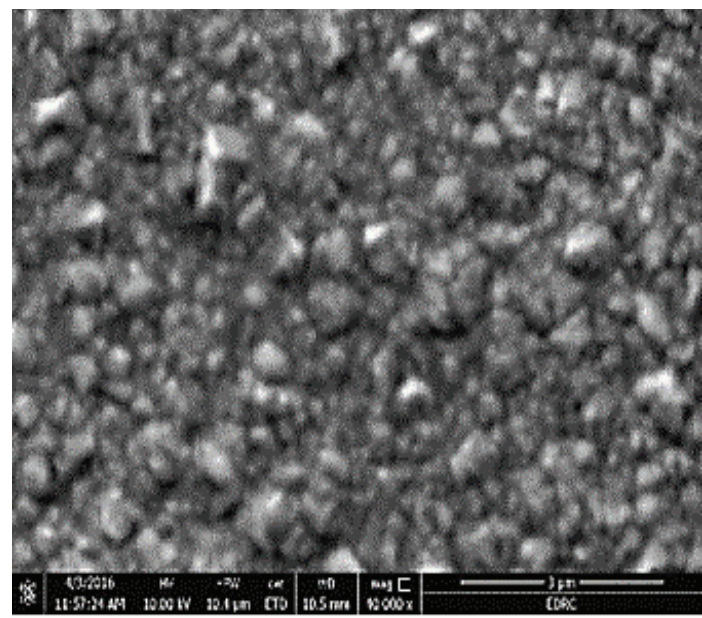

(c)

FIGURE 1: SEM micrographs of nanocrystalline Ni-Co alloys electrodeposited at $30 \mathrm{~mA} / \mathrm{cm}^{2}$ : (a) $15 \mathrm{~min}$, (b) $20 \mathrm{~min}$, and (c) $30 \mathrm{~min}$.

(SCE). Prior to the potentiodynamic test, the samples were immersed in corrosive medium for $30 \mathrm{~min}$ to obtain the open circuit potential " $E_{\mathrm{OCP}}$." After the stabilization of $E_{\mathrm{OCP}}$, the upper and lower potential limits were fixed to $\pm 300 \mathrm{mV}$ with

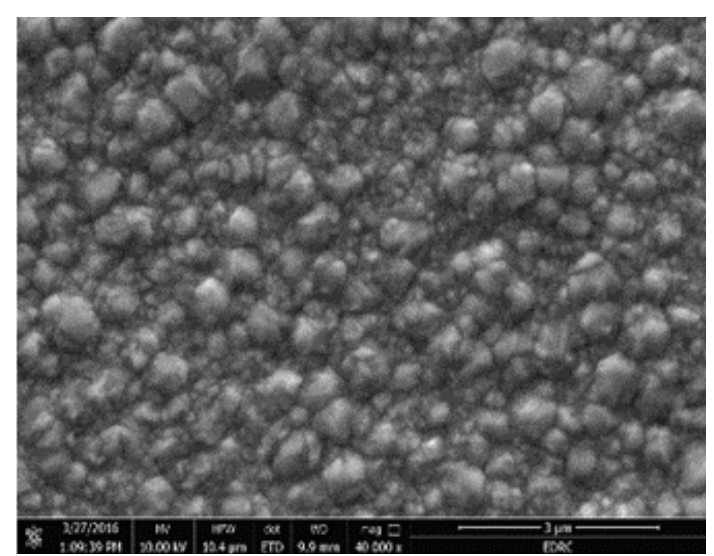

(a)

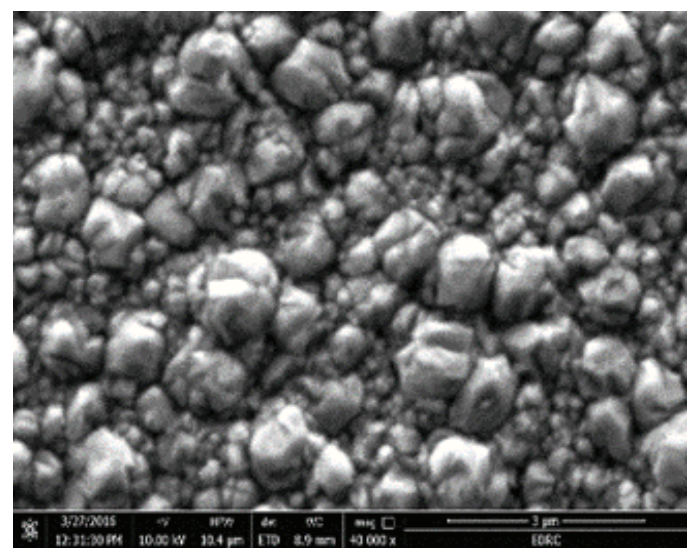

(b)

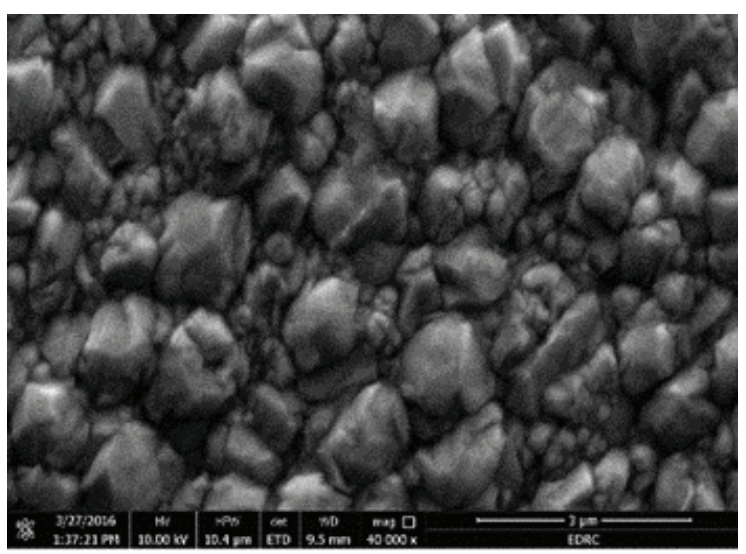

(c)

Figure 2: SEM micrographs of nanocrystalline $\mathrm{Ni}$-Co alloys electrodeposited at $50 \mathrm{~mA} / \mathrm{cm}^{2}$ : (a) $15 \mathrm{~min}$, (b) $20 \mathrm{~min}$, and (c) $30 \mathrm{~min}$.

respect to $E_{\mathrm{OCP}}$, with a scanning rate of $0.33 \mathrm{mV} / \mathrm{s}$. Tafel's plot obtained from polarization studies was displayed, and the corrosion potential $E_{\text {corr }}$ and corrosion current density $I_{\text {corr }}$ were deduced from the plot. The Stern-Geary equation [29] is as follows:

$$
I_{\text {corr }}=\left[\frac{\beta_{a} / \beta_{c}}{2.303\left(\beta_{a}+\beta_{c}\right)}\right] \cdot\left[\frac{1}{R_{\mathrm{p}}}\right]
$$




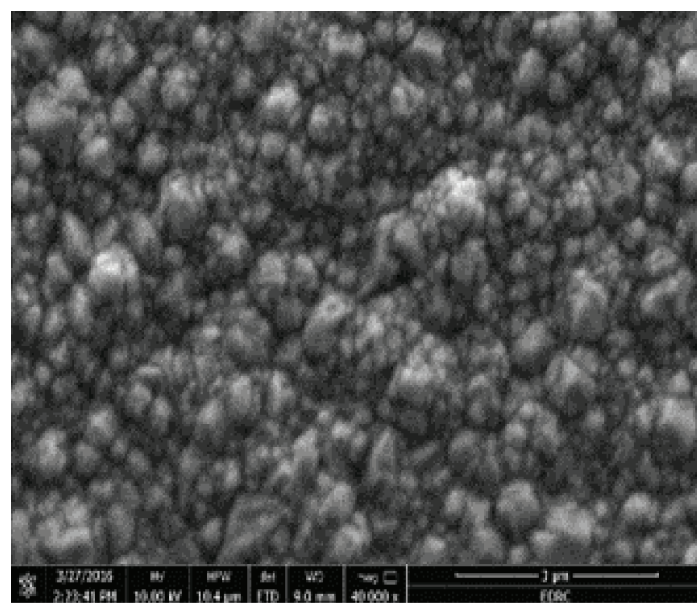

(a)

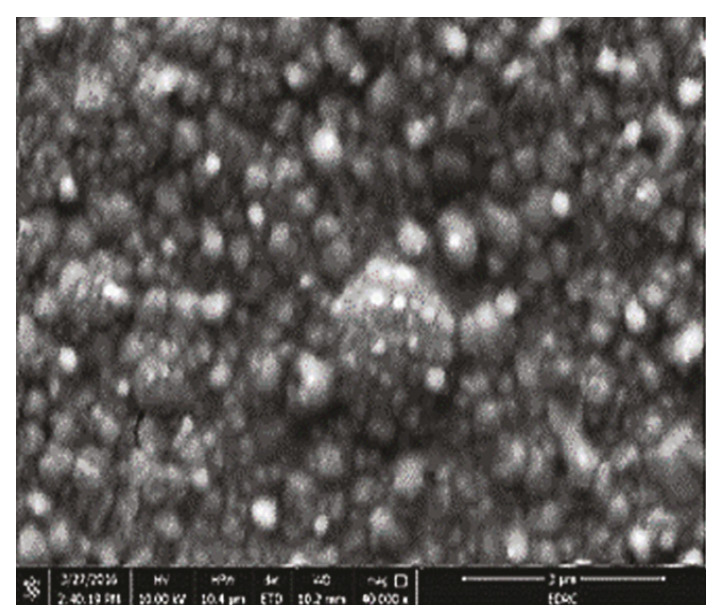

(b)

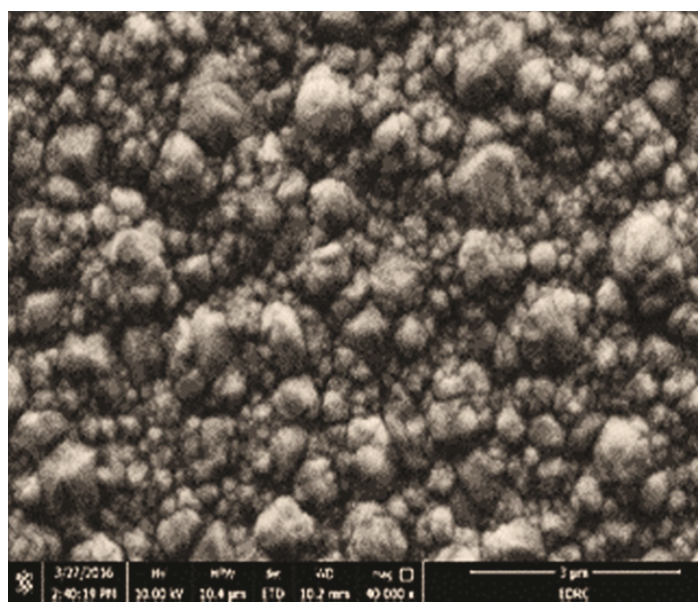

(c)

FIGURE 3: SEM micrographs of nanocrystalline Ni-Co alloys electrodeposited at $80 \mathrm{~mA} / \mathrm{cm}^{2}$ : (a) $15 \mathrm{~min}$, (b) $20 \mathrm{~min}$, and (c) $30 \mathrm{~min}$.

where $\beta_{\mathrm{a}}$ and $\beta_{\mathrm{c}}$ are Tafel's constants expressed as $V /$ dec and $R_{\mathrm{p}}$ is the polarization resistance in $\Omega \cdot \mathrm{cm}^{2}$, was employed to determine the corrosion current $I_{\text {corr }}$.

2.6. EIS and CV. A Gamry potentiostat instrument coupled with a computer software (Gamry software (Series G 300)) was used to draw the Bode and Nyquist plot. Impedance measurements were conducted in the frequency range of $25 \mathrm{kHz}$ to $10 \mathrm{mHz}$, and an amplitude of $10 \mathrm{mV}$ was applied in the open circuit potential. The following information is obtained from EIS tests. The values of the solution resistance " $R_{\mathrm{u}}$ ", polarization resistance " $R_{\mathrm{p}}$ ", double-layer capacitance " $C_{\mathrm{dl}}$ ", constant phase element "CPE $(Y)$," and $\alpha$ are defined from the capacitive impedance equation

$$
Z=\frac{1}{C}(j w)^{-\alpha}
$$

Capacitors in EIS experiments often do not behave ideally. Instead, they act like a constant phase element (CPE). The exponent $\alpha$ is 1 for the ideal capacitance. For a constant phase element, the exponent $\alpha$ is less than one. The "double- layer capacitor" on real cells often behaves like a CPE instead of like an ideal capacitor [14].

The same setup and software were used to obtain the cyclic voltammetry $\mathrm{CV}$ curves. The applied range of potential was 0.1 to 1.1 on an $\mathrm{Ag} / \mathrm{AgCl}$ scale with a scanning rate of $100 \mathrm{mV} / \mathrm{s}$.

\section{Results and Discussions}

3.1. Morphology of the Deposits. The effect of current density on the surface morphology of $\mathrm{Ni}$-Co layers is presented in Figures 1-3. At $30 \mathrm{~mA} / \mathrm{cm}^{2}$ (Figure 1), the morphology of the deposited alloys changed with time from nodular to angular as the time increased from 15 minutes to 30 minutes. The particle size increases with increasing deposition time due to the enough time given for particles to grow [30]. Similarly, at $50 \mathrm{~mA} / \mathrm{cm}^{2}$ (Figure 2), nodular morphology was observed at deposition time of 15 minutes. At 20 minutes, the morphology turned into a mixture of nodular and angular particles and became fully angular by increasing the deposition time further to 30 minutes. At $80 \mathrm{~mA} / \mathrm{cm}^{2}$, the SEM results at $40 \mathrm{KX}$ (Figure 3 ) illustrated a relatively small 
TABLE 3: EDX analysis of electrodeposited nanocrystalline Ni-Co layers.

\begin{tabular}{lccc}
\hline \multirow{2}{*}{ Current density $\left(\mathrm{mA} / \mathrm{cm}^{2}\right)$} & \multirow{2}{*}{ Time $(\mathrm{min})$} & \multicolumn{2}{c}{ Composition } \\
& & \% Ni & $\%$ Co \\
\hline \multirow{3}{*}{30} & 15 & 63.08 & 36.92 \\
& 20 & 62.22 & 37.78 \\
& 30 & 70.56 & 29.44 \\
\hline \multirow{3}{*}{50} & 15 & 66.86 & 33.14 \\
& 20 & 73.86 & 26.23 \\
& 30 & 82.93 & 17.07 \\
\hline \multirow{3}{*}{80} & 15 & 83.16 & 16.84 \\
& 20 & 83.47 & 16.53 \\
& 30 & 84.9 & 15.1 \\
\hline
\end{tabular}

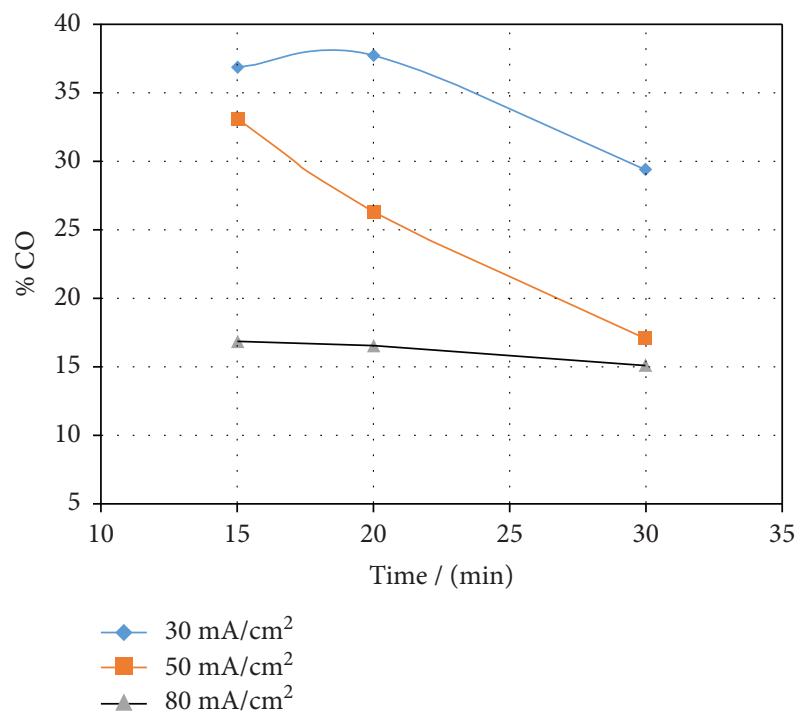

Figure 4: The effect deposition time as well as the current density on the Co content of electrodeposited nanocrystalline Ni-Co alloys.

particle size embedded within the coarse nodules. An increase in overpotential enhances the rate of nucleation and produces a small particle size [31-37].

3.2. EDX Analysis. The chemical composition of nanocrystalline $\mathrm{Ni}$-Co alloys electrodeposited by various applied current densities and deposition time is shown in Table 2. At $30 \mathrm{~mA} /$ $\mathrm{cm}^{2}$, by increasing the deposition time from 15 minutes to 30 minutes, the cobalt content is decreasing from 37 to $29 \mathrm{wt} \%$. This is due to the depletion of $\mathrm{Co}^{2+}$ in the solution or due to the lower deposition efficiency of $\mathrm{Co}$ than that of $\mathrm{Ni}$ and hence a decrease in the ratio of $\mathrm{Co}^{2+} /\left(\mathrm{Ni}^{2+}+\mathrm{Co}^{2+)}[24,38]\right.$. Similarly, at $50 \mathrm{~mA} / \mathrm{cm}^{2}$, the cobalt content decreased from 33 to $17.24 \mathrm{wt} \%$ as the deposition time increased from 15 to 30 minutes. The same trend was recognized by increasing the current density further to $80 \mathrm{~mA} / \mathrm{cm}^{2}$, where the cobalt content dropped down to $15.8 \mathrm{wt} \%$, by increasing the deposition time up to 30 minutes.

The effect of the deposition current densities as well as deposition time on the \% Co content is also summarized in

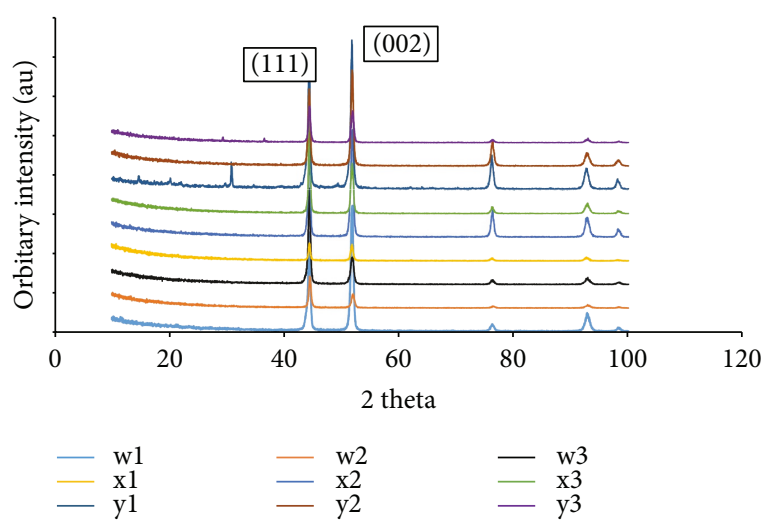

FIGURE 5: XRD pattern of electrodeposited layer of nanocrystalline Ni-Co alloys. ${ }^{*} \mathrm{w},>30 \mathrm{~mA} / \mathrm{cm}^{2} ; \mathrm{x},>50 \mathrm{~mA} / \mathrm{cm}^{2} ; \mathrm{y},>80 \mathrm{~mA} / \mathrm{cm}^{2}$; $1,>15 \mathrm{~min} ; 2$, > $20 \mathrm{~min} ; 3,>30 \mathrm{~min}$.

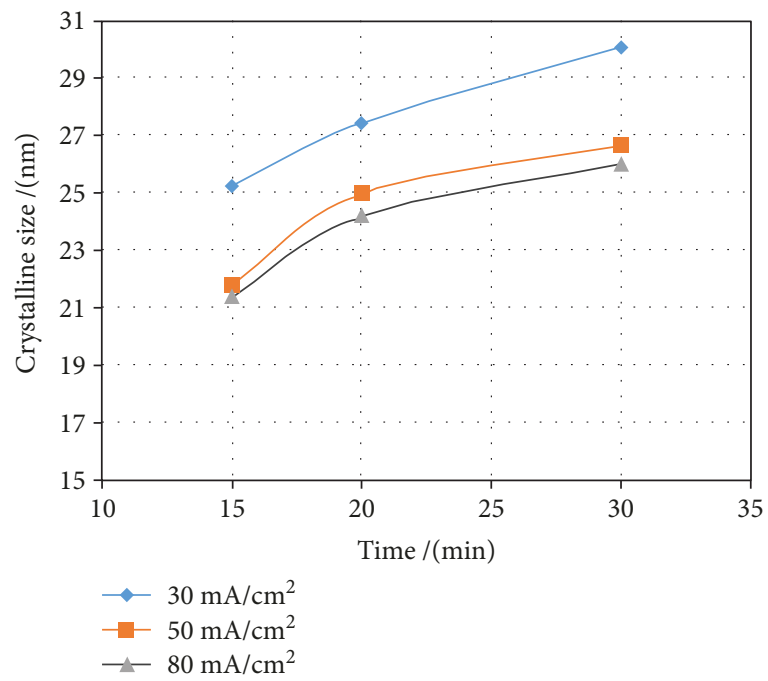

FIgURE 6: The effect of the deposition time as well as the current density on the crystalline size of the electrodeposited nanocrystalline Ni-Co alloys.

Table 3 and Figure 4. According to Rafailović et al. [39], an increase in the current density leads to an increase in the overpotential which is combined by an increase in the activation of the electrode reaction. This leads to a higher nickel content in the Ni-Co deposits.

3.3. X-Ray Diffraction. Figure 5 shows an example of the XRD pattern for electrodeposited nanocrystalline $\mathrm{Ni}-\mathrm{Co}$ alloys. Two sharp peaks for all XRD patterns were detected at $2 \theta$ around $44^{\circ}$ and $52^{\circ}$. Their main textures are (111) and (200). These high peaks suggest that the Ni-Co alloy deposits are considered crystalline in structure. In agreement with other research [33, 37, 40-42], the obtained peaks indicated the deposition of a one-phase Ni-Co solid solution $(\alpha)$ with a face-centered cubic structure. According to the $\mathrm{Ni}$-Co equilibrium phase diagram, the structure consists of the $\alpha$ phase, which is a substitutional solid solution of $\mathrm{Ni}$ and $\mathrm{Co}$ and the structure was face-centered cubic (fcc). When the Co content 


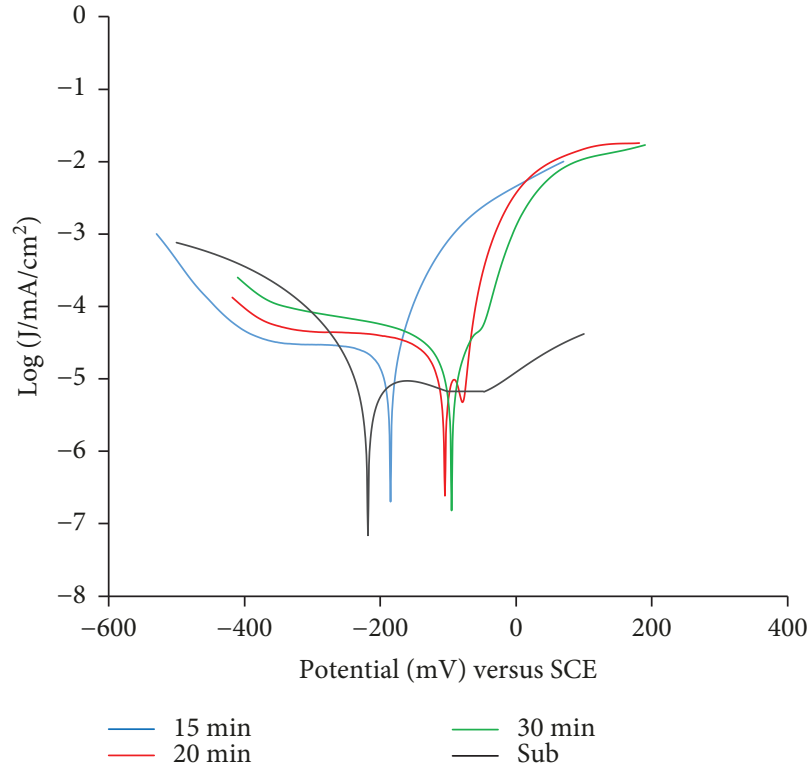

(a) $30 \mathrm{~mA} / \mathrm{cm}^{2}$

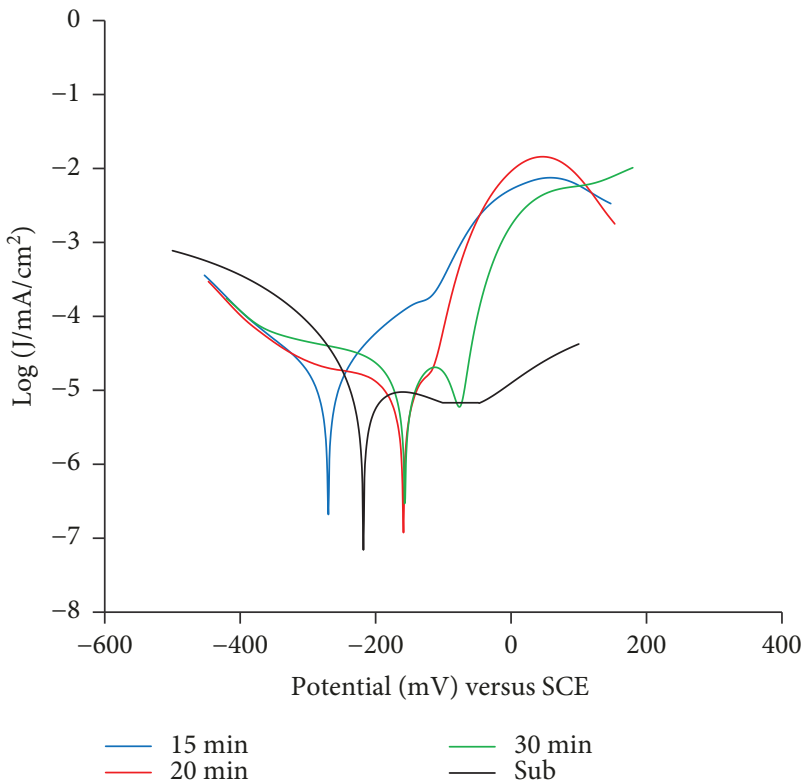

(b) $50 \mathrm{~mA} / \mathrm{cm}^{2}$

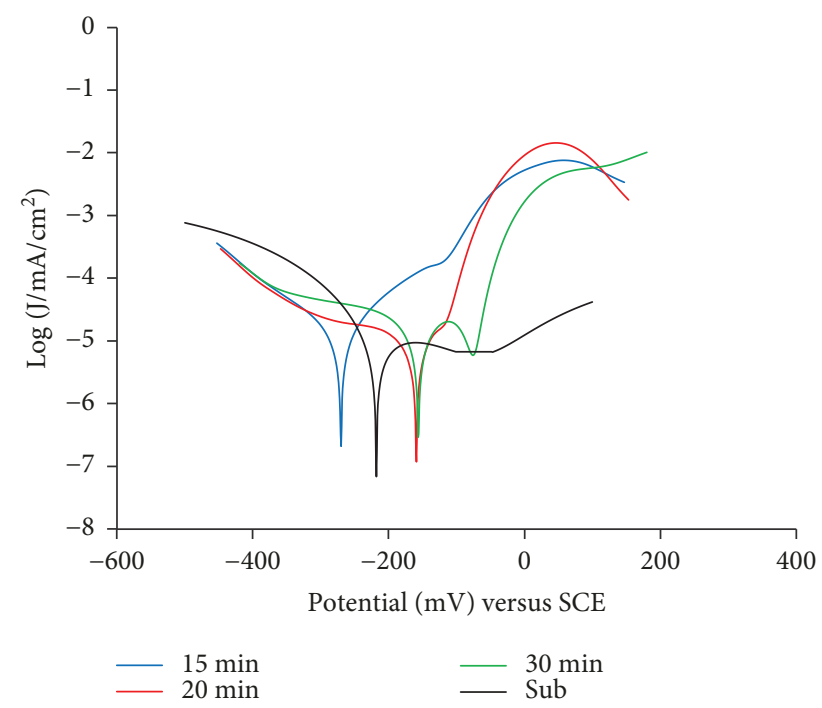

(c) $80 \mathrm{~mA} / \mathrm{cm}^{2}$

Figure 7: Potentiodynamic polarization curves for the nanocrystalline Ni-Co deposits in $1 \mathrm{M}$ methyl alcohol acidic solution.

increases to $50 \%$, the fcc phase turns to a mixed crystalline structure of fcc and hcp [43].

From Figure 4, Ni-Co coatings with higher cobalt contents were obtained under lower current density and less deposition time conditions. In agreement with Yang and Deng [44], the intensity of the main XRD peaks increases and the peak width is broader, indicating a decrease in grain size with higher Co content.

The effect of the current density and deposition time on the crystalline size is illustrated in Figure 6. Generally, a crystalline size ranging from $21 \mathrm{~nm}$ to $30 \mathrm{~nm}$ was obtained. The crystalline size increased slightly with increase in the deposition time at all the deposition current densities due to the presence of enough time for some coarsening of the grains [41]. The effect of the deposition current density on crystalline size is shown in Figure 6 . The crystalline size decreased when the deposition current density increased. This is due to the effect of the overpotential. A higher overpotential is needed for a higher current density. An increase in the overpotential leads to an increase in the nucleation rate and hence a reduction in the crystalline size $[39,45]$.

3.4. Potentiodynamic Polarization Test. Figure 7 displays the polarization of the steel substrate and the deposited nanocrystalline Ni-Co alloys at different current densities and times. From the figure, the anodic branches for all the curves exhibited higher activity or higher current densities than those of the substrate. 


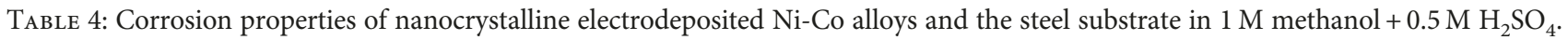

\begin{tabular}{|c|c|c|c|c|c|c|}
\hline Time (min) & $\beta_{\mathrm{a}}$ & $\beta_{\mathrm{c}}$ & $E_{\text {corr }}(\mathrm{mV})$ & $I_{\text {corr }}\left(\mu \mathrm{A} / \mathrm{cm}^{2}\right)$ & Corrosion rate $(\mu \mathrm{m} / \mathrm{y})$ & $R_{\mathrm{p}}(\mathrm{K} \Omega)$ \\
\hline \multicolumn{7}{|l|}{$30 \mathrm{~mA} / \mathrm{cm}^{2}$} \\
\hline 15 & 40.5 & 37.5 & -205.9 & 6.64 & 71.59 & 1.12 \\
\hline 20 & 47.7 & 48 & -162 & 5.93 & 63.95 & 3.27 \\
\hline 30 & 37.7 & 33 & -156.1 & 5.04 & 54.33 & 1.99 \\
\hline \multicolumn{7}{|l|}{$50 \mathrm{~mA} / \mathrm{cm}^{2}$} \\
\hline 15 & 24.9 & 41.6 & -188 & 5.61 & 60.53 & 0.999 \\
\hline 20 & 25.9 & 42.8 & -104 & 4.71 & 50.78 & 1.240 \\
\hline 30 & 27.6 & 36.7 & -97.4 & 3.40 & 36.73 & 1.540 \\
\hline \multicolumn{7}{|l|}{$80 \mathrm{~mA} / \mathrm{cm}^{2}$} \\
\hline 15 & 27.4 & 40 & -116 & 3.53 & 38.11 & 1.95 \\
\hline 20 & 17.1 & 31.6 & -85 & 2.47 & 26.73 & 0.846 \\
\hline 30 & 10.4 & 29.2 & -52.2 & 2.37 & 25.62 & 1.82 \\
\hline \multicolumn{7}{|c|}{ Stainless steel substrate } \\
\hline- & 13.58 & 34.2 & -231 & 1.53 & 11.73 & 8.36 \\
\hline
\end{tabular}

The various electrochemical parameters $\left(\beta_{\mathrm{a}}, \beta_{\mathrm{c}}, E_{\text {corr }}\right.$, $I_{\text {corr }}$, and $R_{\mathrm{p}}$ ) estimated from experimental data are illustrated in Table 4 . The corrosion potential of stainless steel substrate $E_{\text {corr }}$ was observed to be $-231 \mathrm{mV}$. It should be mentioned that a positive shift of $E_{\text {corr }}$ values was observed for coated samples. The shift observed was $-52.2 \mathrm{mV}$ for layers containing $15 \%$ Co. These layers were deposited at current density $80 \mathrm{~mA} / \mathrm{cm}^{2}$ for $30 \mathrm{~min}$.

At $30 \mathrm{~mA} / \mathrm{cm}^{2}$, the values of the corrosion current densities were changed. A slight reduction in corrosion current densities, from 6.64 to $5 \mu \mathrm{A} / \mathrm{cm}^{2}$, with increase in deposition time at constant deposition current density was due to the coarsening of the particle size and hence the small electroactive surface area $[43,46]$. The Co content values were 37 and $33 \%$ for deposition times 15 and 30 minutes, respectively. In addition, the corrosion resistance of the nanocrystalline $\mathrm{Ni}$-Co alloys can be changed by altering the Co content [47]. Srivastava et al. [48] reported poor corrosion behavior of cobalt-rich coatings by increasing the Co content beyond $20 \%$. At $50 \mathrm{~mA} / \mathrm{cm}^{2}$, a further reduction in $I_{\text {corr }}$ from 5.6 to $3.4 \mu \mathrm{A} / \mathrm{cm}^{2}$ was detected with the increase in deposition time. The Co content and the resulting particle size had their effect as interpreted in the case of $30 \mathrm{~mA} / \mathrm{cm}^{2}$. Similarly, at $80 \mathrm{~mA} / \mathrm{cm}^{2}$, the corrosion current dropped down to $2.4 \mu \mathrm{A} / \mathrm{cm}^{2}$. This can be due to the lower Co content obtained at that deposition current density, when compared with the other deposition current densities, for all deposition time periods [49].

In agreement with Kharmachi et al [45], the value of $I_{\text {corr }}$ was decreased and a better corrosion resistance was obtained in the case of nickel-rich deposits. For example, the corrosion rate for Ni-Co containing 37\% Co was $71.59 \mu \mathrm{m} / \mathrm{y}$ compared to $26 \mu \mathrm{m} / \mathrm{y}$ for a layer containing $16 \%$ Co.

Paul and Naimuddin [50] stated that the polarization curves for coated materials shift to the right in comparison to a bare stainless steel surface, which indicates that Ni-Co coatings always produce higher current.
According to Naimuddin [51], the higher $I_{\text {corr }}$ as well as corrosion rate values for $\mathrm{Ni}-\mathrm{Co}$ deposits $(\cong 72-26 \mu \mathrm{m} / \mathrm{y})$, compared with that of the substrate $(11 \mu \mathrm{m} / \mathrm{y})$, are due only to the oxidation of methanol and not due to any corrosion of the nanocrystalline Ni-Co alloy surface. Electrodeposition of $\mathrm{Ni}$-Co alloys on stainless steel substrate has been carried out to obtain a high current density electrocatalytic surface with minimum polarization resistance for the anodic oxidation reaction of methyl alcohol. Generally, the nanocrystalline $\mathrm{Ni}-\mathrm{Co}$ alloys showed lower polarization resistance (1$3.27 \mathrm{~K} \Omega$ ) than that of the steel substrate $(8.36 \mathrm{~K} \Omega)$. This is an evidence for the higher electrochemical activity and ease in charge transfer between the nanocrystalline Ni-Co alloys and the used electrolyte than that of the steel substrate of higher polarization resistance [51].

Methanol electrooxidation is a complex reaction occurring in a pattern of parallel reaction pathways [50, 52]. Although detailed reaction mechanisms remain obscure, a number of reaction intermediates and products have been identified. The complete oxidation of methanol yields $\mathrm{CO}_{2}$ and six electrons per methanol molecule as shown in (3). Methanol has a low theoretical oxidation potential $(0.02 \mathrm{~V})$ comparable to that of hydrogen $(0.0 \mathrm{~V})$, and in principle, it can be an efficient fuel at low temperatures.

$$
\mathrm{CH}_{3} \mathrm{OH}_{(\mathrm{L})}+\mathrm{H}_{2} \mathrm{O}_{(\mathrm{l})} \rightarrow \mathrm{CO}_{2(\mathrm{~g})}+6 \mathrm{H}^{+}+6 \mathrm{e}^{-}
$$

$\mathrm{H}^{+}$generated during oxidation of methyl alcohol gets diffused into a cathodic chamber through the membrane and supplies $\mathrm{H}^{+}$ions for the cathodic reduction reaction of $\mathrm{O}_{2}$ to pure water [50].

3.5. EIS Test. Figure 8 shows the impedance plots of the nanocrystalline Ni-Co alloys deposited at $30 \mathrm{~mA} / \mathrm{cm}^{2}$ and the steel substrate. In agreement with many previous publications [50-53], the substrate had a larger diameter arc in the Nyquist plots (Figure 8(a)) and higher modulus impedance 


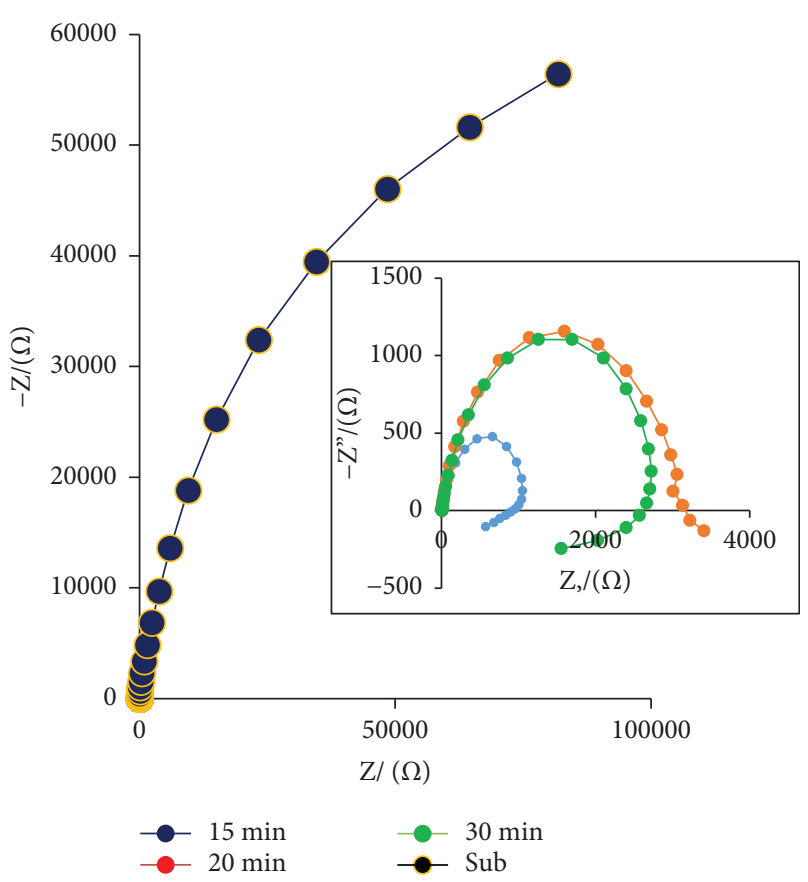

(a) Nyquist plot

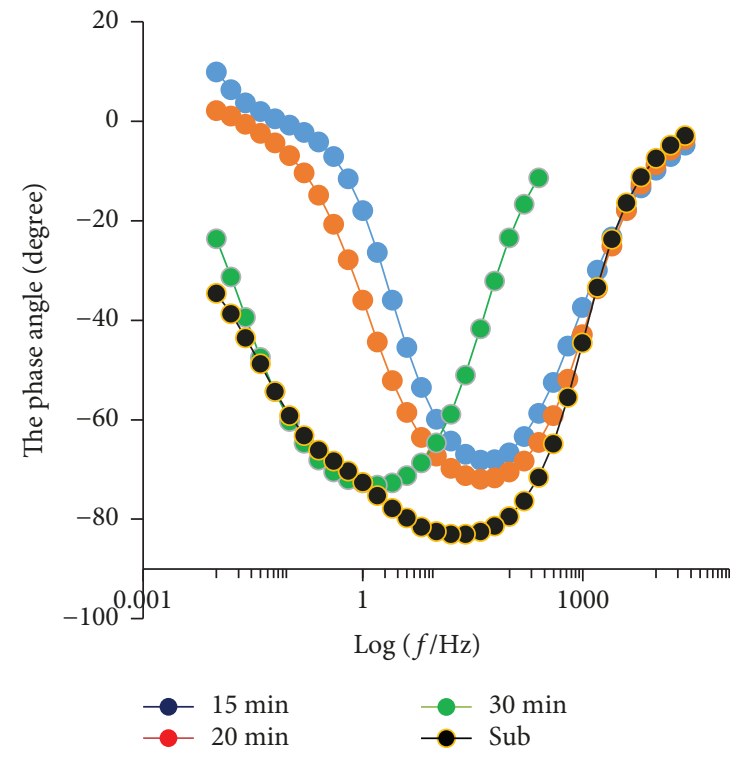

(c) Bode plot (phase angle with the frequency)

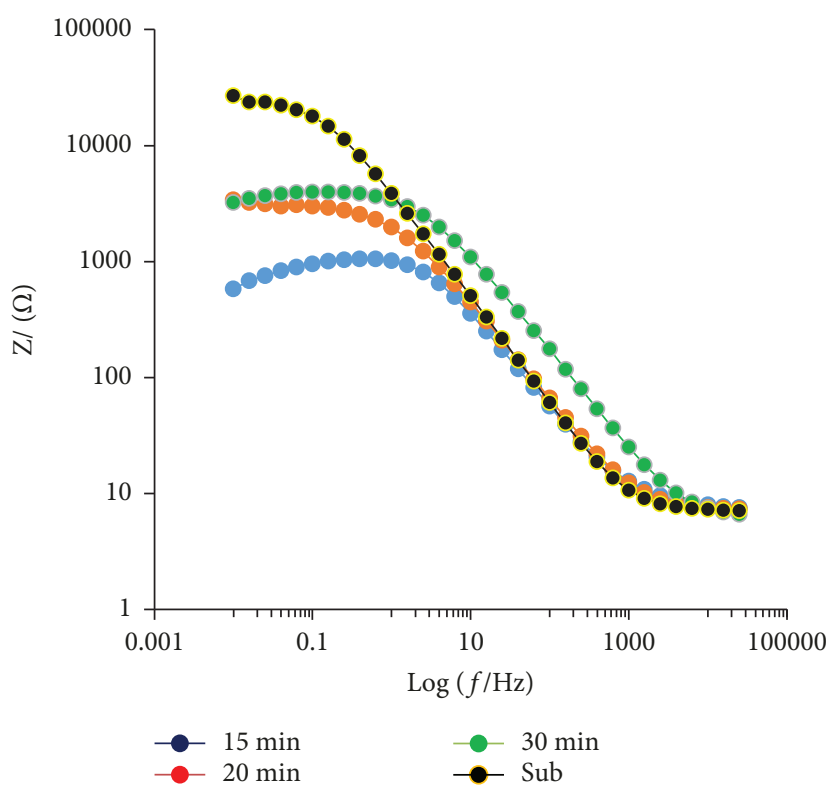

(b) Bode plot (impedance modulus versus the frequency)

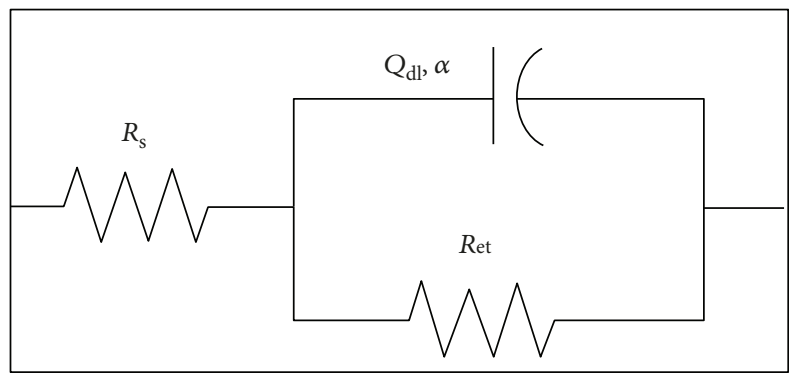

Figure 8: EIS plots of the nanocrystalline Ni-Co alloys deposited at $30 \mathrm{~mA} / \mathrm{cm}^{2}$ and the steel substrate tested in $1 \mathrm{~m}$ methyl alcohol acidic solution.

in the Bode plots (Figure $8(\mathrm{~b})$ ), with a more positive phase angle (Figure $8(\mathrm{c})$ ) than those of the electrodeposited nanocrystalline Ni-Co electrodes. This means that Ni-Co electrodes had lower impedance to charge transfer than the steel substrate when being subjected to methyl alcohol. The phase angle of the deposited nanocrystalline Ni-Co electrodes was in the range of -10 to -70 degrees compared to a range from 0 to near -90 degrees for the steel substrate. This is due to the fact that when using the steel substrate, the double layer acts as a pure capacitive load for charge transfer. Meanwhile, in case of using the Ni-Co electrodes, the matter is different and lower impedance to charge transfer occurs.

From Table 5, it can be concluded that Ni-Co layers showed significantly lower polarization resistance than the stainless steel substrates did. In addition, using a current density of $30 \mathrm{~mA} / \mathrm{cm}^{2}$, the polarization resistance did not have a clear trend and was in the range of 1.82 to $3.09 \mathrm{~K} \Omega$. At a current density of $50 \mathrm{~mA} / \mathrm{cm}^{2}$, the polarization resistance decreased with increasing deposition time and was in the 
TABLE 5: The EIS results of all electrodeposited nanocrystalline $\mathrm{Ni}$-Co alloys tested in $1 \mathrm{M}$ methanol $+0.5 \mathrm{M} \mathrm{H}_{2} \mathrm{SO}_{4}$.

\begin{tabular}{lcccc}
\hline Time $(\mathrm{min})$ & $R_{\mathrm{p}}(\mathrm{K} \Omega)$ & $R_{\mathrm{u}}(\Omega)$ & $Y\left(\mu \mathrm{F} / \mathrm{cm}^{2}\right)$ & $\alpha$ \\
\hline $30 \mathrm{~mA} / \mathrm{cm}^{2}$ & & & & \\
15 & 1.82 & 7.917 & 63.5 & 0.88 \\
20 & 3.09 & 7.178 & 63.3 & 0.86 \\
30 & 2.39 & 7.714 & 35.9 & 0.86 \\
$50 \mathrm{~mA} / \mathrm{cm}^{2}$ & & & & \\
15 & 7.99 & 7.425 & 15.6 & 0.85 \\
20 & 2.64 & 7.31 & 18.8 & 0.86 \\
30 & 1.71 & 6.969 & 22.8 & 0.89 \\
$80 \mathrm{~mA} / \mathrm{cm}^{2}$ & & & & \\
15 & 3.6 & 7.137 & 51.8 & 0.843 \\
20 & 2.27 & 6.916 & 27.8 & 0.845 \\
30 & 2.53 & 7.122 & 37.5 & 0.814 \\
Stainless steel substrate & & & \\
- & 103 & 7.271 & 42.9 & 0.89 \\
\hline
\end{tabular}

range of 1.71 to $7.99 \mathrm{~K} \Omega$, which is lower than that of the steel substrate $(103 \mathrm{~K} \Omega)$. A similar trend was observed using a current density $80 \mathrm{~mA} / \mathrm{cm}^{2}$. The polarization resistance was in the range of 1.8 to $8 \mathrm{~K} \Omega$, which is also lower than that of the steel substrate $[54,55]$. The specimen deposited at $50 \mathrm{~mA} / \mathrm{cm}^{2}$ for 30 minutes showed the lowest polarization value $(1.71 \mathrm{~K} \Omega)$, which corresponds to the highest electrocatalytic activity for hydrogen evolution.

The solution resistance $(R \mathrm{u})$ was changed in all the specimens by a small degree due to the use of the same methanol electrolyte. There is no uniform behavior in the constant phase element (CPE) values with varying deposition current densities or deposition times. The exponent $\alpha$ was changed in a small range from 0.845 to 0.89 . According to Paul and Naimuddin [50], this exponent exists due to the nonideal behavior of the double-phase capacitance. The electric circuit which models the interface is shown in Figure 8(d).

3.6. CV Test. Methanol oxidation was examined on nanocrystalline Ni-Co electrodes by $\mathrm{CV}$ measurements, and results are shown in Table 6 and Figure 9. Methanol electrooxidation on the catalysts electrodes showed two oxidation peaks in the forward and reverse sweeps. In the forward scan, the observed peak is related to the oxidation of freshly chemisorbed species coming from methanol adsorption. In the backward sweep, the oxidation corresponds to removal of the carbonaceous species (CO gas) that have not completely oxidized in the forward scan. The oxidation of intermediate, mainly CO, is shown in [56]

$$
\mathrm{Ni}-\mathrm{CO}_{\mathrm{ads}}+\mathrm{Co}-\mathrm{OH}_{\mathrm{ads}} \rightarrow \mathrm{CO}_{2}+\mathrm{H}^{+}+\mathrm{e}^{-}
$$

At $30 \mathrm{~mA} / \mathrm{cm}^{2}$ (Figure 9(a)), the effect of the deposition time on forward peak current densities is very clear. An increase in the deposition time from 15 to 30 min leads to an increase in $J_{\mathrm{p}}$ from 3.15 to $9.25 \mathrm{~mA} / \mathrm{cm}^{2}$, due to an
TABLE 6: The results obtained from the CV curves performed to nanocrystalline $\mathrm{Ni}$-Co deposits $1 \mathrm{M}$ methanol $+0.5 \mathrm{M} \mathrm{H}_{2} \mathrm{SO}_{4}$.

\begin{tabular}{lcccc}
\hline Time $(\mathrm{min})$ & $E_{\text {onset }}(\mathrm{mV})$ & $E_{\mathrm{p}}(\mathrm{V})$ & $J_{\mathrm{p}}\left(\mathrm{mA} / \mathrm{cm}^{2}\right)$ & $\frac{I_{\mathrm{f}}}{I_{\mathrm{b}}}$ \\
\hline $30 \mathrm{~mA} / \mathrm{cm}^{2}$ & & & & \\
15 & -0.445 & 0.318 & 3.15 & 5.03 \\
20 & -0.438 & 0.370 & 6.20 & 16.40 \\
30 & -0.545 & 0.358 & 9.25 & 26.27 \\
$50 \mathrm{~mA} / \mathrm{cm}^{2}$ & & & & \\
15 & -0.348 & 0.292 & 16.5 & 40.24 \\
20 & -0.438 & 0.361 & 14.27 & 17.29 \\
30 & -0.545 & 0.31 & 29.6 & 64.20 \\
$80 \mathrm{~mA} / \mathrm{cm}^{2}$ & & & & \\
15 & -0.445 & 0.229 & 5.417 & 10.74 \\
20 & -0.349 & 0.292 & 24.38 & 93.05 \\
30 & -0.445 & 0.468 & 33.3 & 59.73118 \\
\hline
\end{tabular}

increase in the electrochemical active surface area by the presence of subparticles on the relatively larger particles [57]. Longer deposition was also accompanied by reduction in the cobalt content. According to Xu et al. [58], a decrease in Co content leads to an increase in the forward peak current. The broadening of the peaks at 15 and 30 minutes provided a wide a range of potential to achieve the highest current density.

Similar trends were observed, at $50 \mathrm{~mA} / \mathrm{cm}^{2}$ (Figure 9(b)) and $80 \mathrm{~mA} / \mathrm{cm}^{2}$. The longer the deposition time, the higher the forward-to-backward ratio. This means higher efficiency of the electrodeposited nanocrystalline Ni-Co electrodes for more methanol electrooxidation and excellent oxidation of the strongly adsorbed $\mathrm{CO}$ on the surface of the electrode.

Figure 10 shows the effect of the deposition time as well the deposition current density on the forward peak current density $\left(J_{\mathrm{p}}\right)$ of electrodeposited nanocrystalline Ni-Co electrodes. An increase in the deposition time and current density resulted in a higher forward peak current density $J_{\mathrm{p}}$ and thus higher electrocatalytic activity of Ni-Co deposits.

\section{Conclusion}

An increase in the deposition current density as well as deposition time leads to deposition of $\mathrm{Ni}$-Co alloys characterized by a coarse angular morphology with lower cobalt content. Generally, a crystalline size ranging from $21 \mathrm{~nm}$ to $30 \mathrm{~nm}$ was obtained. The crystal size increased slightly with the increase in the deposition time at all the deposition current densities. The obtained XRD peaks indicated the deposition of a one-phase Ni-Co solid solution $(\alpha)$ with a facecentered cubic structure. The corrosion resistance of the nanocrystalline Ni-Co alloys has been changed by altering the Co content. The higher $I_{\text {corr }}$ values for Ni-Co deposits, compared with those of the substrate, are due only to oxidation of methanol and not due to any corrosion of the 


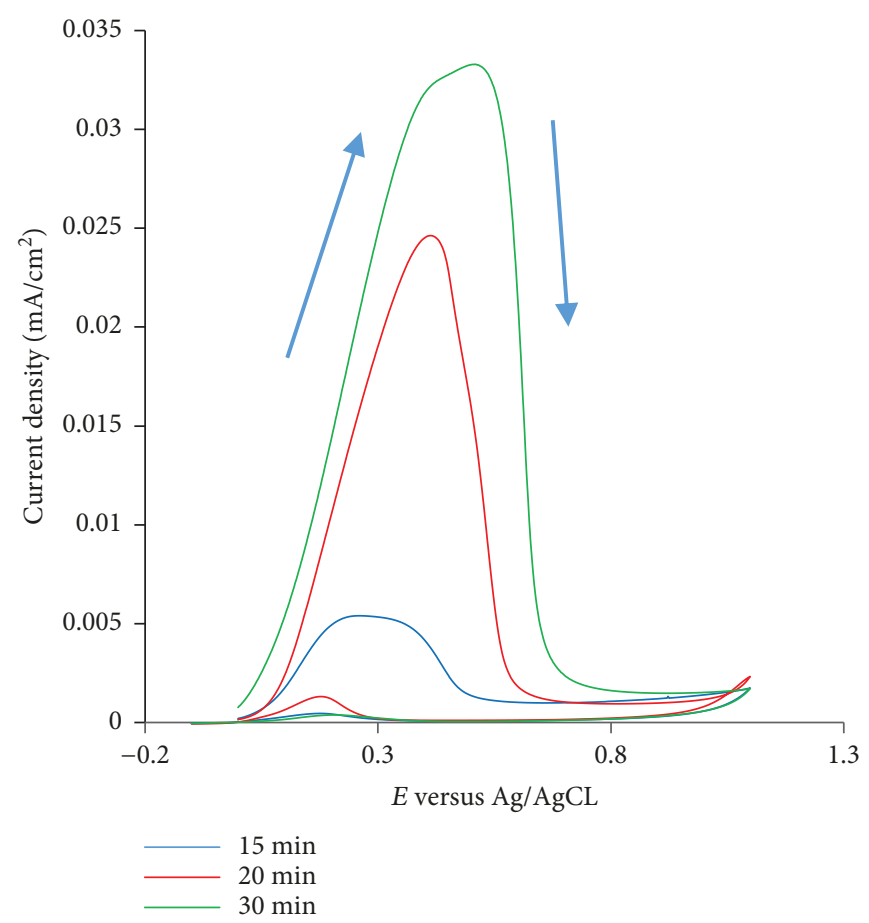

(a) $30 \mathrm{~mA} / \mathrm{cm}^{2}$

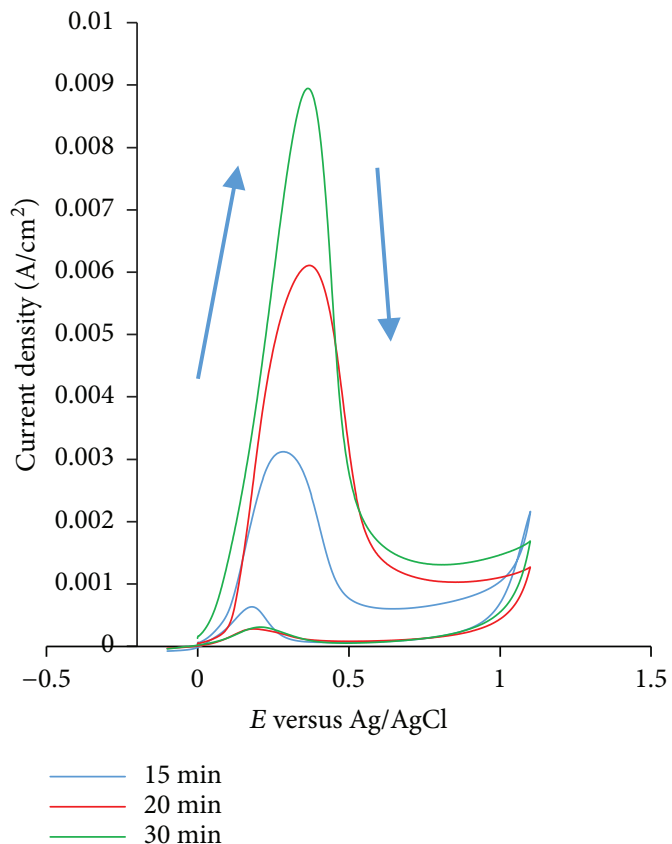

(b) $50 \mathrm{~mA} / \mathrm{cm}^{2}$

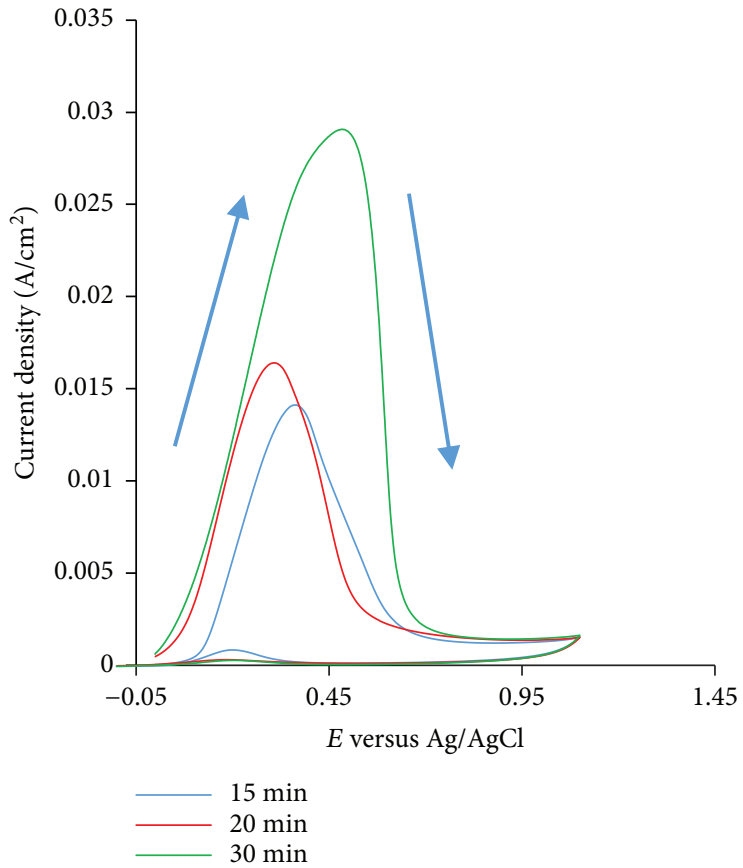

(c) $80 \mathrm{~mA} / \mathrm{cm}^{2}$

Figure 9: The CV curves for electrodeposited nanocrystalline Ni-Co alloys samples prepared at different current densities, in $1 \mathrm{M}$ methanol acidic solution.

nanocrystalline Ni-Co alloy surface. According to the EIS test, the deposited nanocrystalline Ni-Co alloy had less impedance to charge transfer through the interface. The appearance of the forward and backward peaks in the CV test means high activity to methanol oxidation and higher resistance to CO poisoning. The longer the deposition time, the higher the forward-to-backward ratio and hence the higher the efficiency of the electrodeposited nanocrystalline Ni-Co electrodes for more methanol electrooxidation and excellent oxidation of the strongly adsorbed $\mathrm{CO}$ on the surface of the electrode. An increase in the deposition time as well as the current density resulted in a higher forward peak 


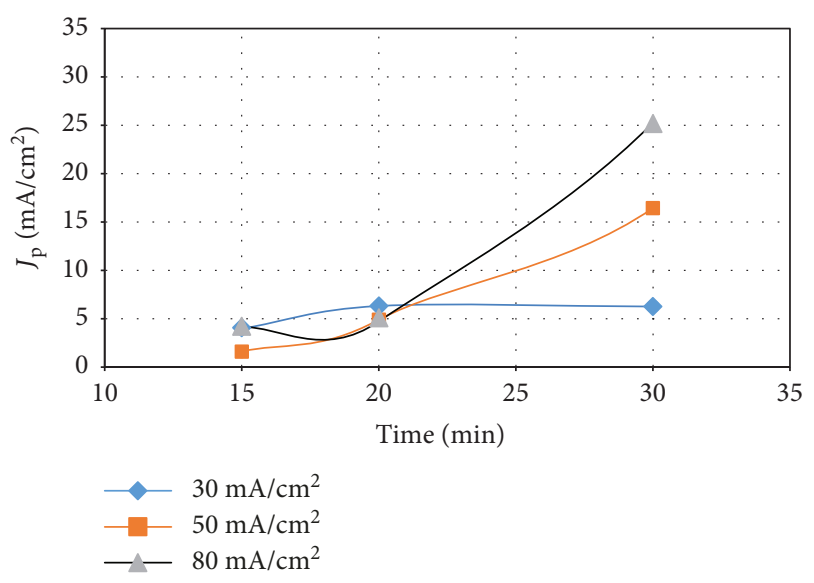

FIGURE 10: The effect of the deposition time as well as the deposition current density on the forward peak current density, obtained from $\mathrm{CV}$ curves conducted for nanocrystalline Ni-Co alloys, in $1 \mathrm{M}$ methanol acidic solution.

current density $J_{\mathrm{p}}$ and thus higher electrocatalytic activity of Ni-Co deposits.

\section{Conflicts of Interest}

The authors declare that there is no conflict of interest regarding the publication of this paper.

\section{References}

[1] H. Liu and J. Zhang, Electrocatalysis of Direct Methanol Fuel Cells, vol. 1, Wiley-VCH Verlag GmbH \& Co. KGaA, Weinheim, 1st edition edition, 2009.

[2] EG\&G Technical Services Inc., Science Applications International Corporation, Fuel Cell Handbook, EG\&G Technical Services, Inc US Department of Energy Office of Fossil Energy National Energy Technology Laboratory, Morgantown, West Virginia, Seventh Edition edition, 2004.

[3] C. Rayment and S. Sherwin, Introduction to Fuel Cell Technology, vol. 1, Notre Dame, USA, 1st edition edition, 2003.

[4] J. Larminie and A. Dicks, Fuel Cell Systems Explained, vol. 1, John Wiley \& Sons Ltd, England, 2nd edition edition, 2003.

[5] J.-H. Wee, "Applications of proton exchange membrane fuel cell systems," Renewable and Sustainable Energy Reviews, vol. 11, no. 8, pp. 1720-1738, 2007.

[6] J. Xuan, M. K. H. Leung, D. Y. C. Leung, and M. Ni, "A review of biomass-derived fuel processors for fuel cell systems," Renewable and Sustainable Energy Reviews, vol. 13, no. 6-7, pp. 1301-1313, 2009.

[7] S. Paul and A. Jana, "Study on bioelectrochemical fuel cell with algae," Journal of the Institution of Engineers (India): Environmental Engineering Division, vol. 88, pp. 7-30, 2007.

[8] S. Paul and P. Mondal, "Pyrolysis of forest residue for production of bio fuel," International Energy Journal, vol. 7, no. 3, pp. 221-225, 2006.

[9] A. E. Lutz, R. S. Larson, and J. O. Keller, “Thermodynamic comparison of fuel cells to the Carnot cycle," International Journal of Hydrogen Energy, vol. 27, no. 10, pp. 1103-1111, 2002.
[10] H. Hassanzadeh and S. H. Mansouri, "Efficiency of ideal fuel cell and Carnot cycle from a fundamental perspective," Proceedings of the Institution of Mechanical Engineers, Part A: Journal of Power and Energy, vol. 219, no. 4, pp. 245-254, 2005.

[11] J. Lee, "Biological conversion of lignocellulosic biomass to ethanol," Journal of Biotechnology, vol. 56, no. 1, pp. 1-24, 1997.

[12] J. Iranmahboob, F. Nadim, and S. Monemi, "Optimizing acidhydrolysis: a critical step for production of ethanol from mixed wood chips," Biomass and Bioenergy, vol. 22, no. 5, pp. 401404, 2002.

[13] D. J. Schell, C. J. Riley, N. Dowe et al., "A bioethanol process development unit: initial operating experiences and results with a corn fiber feedstock," Bioresource Technology, vol. 91, no. 2, pp. 179-188, 2004.

[14] S. Paul and A. Ghosh, "Synthesis and characterization of $\mathrm{MnO}_{2}$ as electrocatalytic energy material for fuel cell electrode," Chemistry and Materials Research, vol. 6, no. 10, pp. 60-72, 2014.

[15] S. Paul, "Characterization of bioelectrochemical fuel cell fabricated with agriculture wastes and surface modified electrode materials," Journal of Fuel Cell Science and Technology, vol. 9, no. 2, pp. 021013-0210122, 2012.

[16] R. Basnayake, Z. Li, S. Katar et al., "PtRu nanoparticle electrocatalyst with bulk alloy properties prepared through a sonochemical method," Langmuir, vol. 22, no. 25, pp. $10446-$ 10450, 2006.

[17] C. Bock, C. Paquet, M. Couillard, G. A. Botton, and B. R. MacDougall, "Size-selected synthesis of PtRu nano-catalysts: reaction and size control mechanism," Journal of the American Chemical Society, vol. 126, no. 25, pp. 8028-8037, 2004.

[18] J. Luo, P. N. Njoki, Y. Lin, L. Wang, and C. J. Zhong, “Activitycomposition correlation of AuPt alloy nanoparticle catalysts in electrocatalytic reduction of oxygen," Electrochemistry Communications, vol. 8, no. 4, pp. 581-587, 2006.

[19] M. Mohamedi, Y. Hisamitsu, K. Kihara, T. Kudo, T. Itoh, and I. Uchida, "Ni-Al alloy as alternative cathode for molten carbonate fuel cells," Journal of Alloys and Compounds, vol. 315, no. 1-2, pp. 224-233, 2001.

[20] K. S. Kumar, P. Haridoss, and S. K. Seshadri, "Synthesis and characterization of electrodeposited Ni-Pd alloy electrodes for methanol oxidation," Surface and Coating Technology, vol. 202, no. 9, pp. 1764-1770, 2008.

[21] R. Karslioğlu, M. Uysal, A. Alp, and H. Akbulut, "Reciprocating Wear Behavior of Ni-Co alloys produced by pulse current electrodeposition," Acta Physica Polonica A, vol. 123, no. 2, pp. 424-426, 2013.

[22] D. S. Schweckandt and M. del Carmen Aguirre, "Electrodeposition of Ni-Co alloys. Determination of properties to be used as coins," Procedia Materials Science, vol. 8, pp. 91-100, 2015.

[23] P. P. Włodarczyk and B. Włodarczyk, "Possibility of using Nico alloy as catalyst for oxygen electrode of fuel cell," Chinese Business Review, vol. 14, no. 3, pp. 159-167, 2015.

[24] Z. W. Wu, Y. P. Lei, Y. Wang, and H. G. Fu, "Effect of cobalt content on microstructure and property of electroplated nickel-cobalt alloy coatings," Materialwissenschaft und Werkstofftechnik, vol. 44, no. 7, pp. 593-600, 2013.

[25] J. Halim, R. Abdel-Karim, S. El-Raghy, M. Nabil, and A. Waheed, "Electrodeposition and characterization of nanocrystalline Ni-Mo catalysts for hydrogen production," Journal of Nanomaterials, vol. 2012, Article ID 845673, 9 pages, 2012. 
[26] R. Abdel-Karim, Y. Reda, M. Muhammed, S. El-Raghy, M. Shoeib, and H. Ahmed, "Electrodeposition and characterization of nanocrystalline Ni-Fe alloys," Journal of Nanomaterials, vol. 2011, Article ID 519274, 8 pages, 2011.

[27] R. Abdel-Karim, A. Abdel-Fatah, H. A. Ahmed, and S. M. ElRaghy, "Study on nano-deposited Ni-based electrodes for hydrogen evolution from sea water electrolysis," International Journal of Latest Research in Engineering and Technology (IJLRET), vol. 2, no. 1, pp. 15-26, 2016.

[28] R. Abdel-Karim, J. Halim, S. El-Raghy, M. Nabil, and A. Waheed, "Surface morphology and electrochemical characterization of electrodeposited $\mathrm{Ni}-\mathrm{Mo}$ nanocomposites as cathodes for hydrogen evolution," Journal of Alloys and Compounds, vol. 530, pp. 85-90, 2012.

[29] M. Stern and A. L. Geaby, "Electrochemical polarization. I. A theoretical analysis of the shape of polarization curves," Journal of the Electrochemical Society, vol. 104, no. 1, pp. 56-63, 1957.

[30] N. A. Resali, K. M. Hyie, M. N. Berhan, Z. Salleh, and S. Kasolang, "Cobalt-nickel-iron nanoparticles coated on stainless steel substrate," Procedia Engineering, vol. 68, pp. 30-36, 2013.

[31] Y. D. Gamburg and G. Zangari, Theory and Practice of Metal Electrodeposition, Springer, New York, 1 edition, 2011.

[32] V. D. Jović, B. M. Jović, M. G. Pavlović, and V. Maksimović, "Morphology and composition of Ni-Co alloy powders electrodeposited from ammoniacal electrolyte," Journal of Solid State Electrochemistry, vol. 10, no. 12, pp. 959-966, 2006.

[33] M. Spasojević, L. Ribić-Zelenović, and A. Maričić, “The phase structure and morphology of electrodeposited nickel-cobalt alloy powders," Science of Sintering, vol. 43, no. 3, pp. 313326, 2011.

[34] T. Watanabe, Nano-Plating: Microstructure Control Theory of Plated Film and Data Base of Plated Film Microstructure, vol. 1, Elsevier Ltd, 2004.

[35] J. L. McCrea, G. Palumbo, G. D. Hibbard, and U. Erb, "Properties and applications for electrodeposited nanocrystalline Fe-Ni alloys," Reviews on Advanced Materials Science, vol. 5, no. 3, pp. 252-258, 2003.

[36] A. N. Correia and S. A. S. Machado, "Electrodeposition and characterisation of thin layers of Ni-Co alloys obtained from dilute chloride baths," Electrochimica Acta, vol. 45, no. 11, pp. 1733-1740, 2000.

[37] M. Zamani, A. Amadeh, and S. M. Lari Baghal, "Effect of Co content on electrodeposition mechanism and mechanical properties of electrodeposited Ni-Co alloy," Transactions of the Nonferrous Metals Society of China, vol. 26, no. 2, pp. 484-491, 2016.

[38] S. H. Hong, S. H. Ahn, I. Choi et al., "Fabrication and evaluation of nickel-cobalt alloy electrocatalysts for alkaline water splitting," Applied Surface Science, vol. 307, pp. 146152, 2014.

[39] L. D. Rafailović, H. P. Karnthaler, T. Trišović, and D. M. Minić, "Microstructure and mechanical properties of disperse Ni-Co alloys electrodeposited on Cu substrates," Materials Chemistry and Physics, vol. 120, no. 2-3, pp. 409-416, 2010.

[40] M. A. Farzaneh, K. Raeissi, and M. A. Golozar, "Effect of current density on deposition process and properties of nanocrystalline Ni-Co-W alloy coatings," Journal of Alloys and Compounds, vol. 489, no. 2, pp. 488-492, 2010.
[41] H. El-Feky, M. Negem, S. Roy, N. Helal, and A. Baraka, "Electrodeposited $\mathrm{Ni}$ and $\mathrm{Ni}$-Co alloys using cysteine and conventional ultrasound waves," SCIENCE CHINA Chemistry, vol. 56, no. 10, pp. 1446-1454, 2013.

[42] D. Golodnitsky, Y. Rosenberg, and A. Ulus, "The role of anion additives in the electrodeposition of nickel/cobalt alloys from sulfamate electrolyte," Electrochimica Acta, vol. 47, no. 17, pp. 2707-2714, 2002.

[43] G. A. Camara and T. Iwasita, "Parallel pathways of ethanol oxidation: the effect of ethanol concentration," Journal of Electroanalytical Chemistry, vol. 578, no. 2, pp. 315-321, 2005.

[44] Y.-Y. Yang and B. Deng, "Preparation of Ni-Co alloy foils by electrodeposition," Advances in Chemical Engineering and Science, vol. 1, no. 2, pp. 27-32, 2011.

[45] I. Kharmachi, L. Dhouibi, P. Berçot, and M. Rezrazi El, "Codeposition of Ni-Co alloys on carbon steel and corrosion resistance," Journal of Materials and Environmental Science, vol. 6, no. 7, pp. 1807-1812, 2015.

[46] Y. Ma, R. Wang, H. Wang et al., "The effect of PtRuIr nanoparticle crystallinity in electrocatalytic methanol oxidation," Materials, vol. 6, no. 5, pp. 1621-1631, 2013.

[47] J. Wang, P. Holt-Hindle, D. MacDonald, D. F. Thomas, and A. Chen, "Synthesis and electrochemical study of Pt-based nanoporous materials," Electrochimica Acta, vol. 53, no. 23, pp. 6944-6952, 2008.

[48] M. Srivastava, V. Ezhil Selvi, V. K. William Grips, and K. S. Rajam, "Corrosion resistance and microstructure of electrodeposited nickel-cobalt alloy coatings," Surface and Coating Technology, vol. 201, no. 6, pp. 3051-3060, 2006.

[49] B. Bakhit and A. Akbari, "Effect of particle size and codeposition technique on hardness and corrosion properties of Ni-Co/SiC composite coatings," Surface and Coating Technology, vol. 206, no. 23, pp. 4964-4975, 2012.

[50] S. Paul and S. Naimuddin, "Electrochemical characterization of synthesized Ni-Co and $\mathrm{Ni}-\mathrm{Co}-\mathrm{Fe}$ electrodes for methanol fuel cell," Journal of Fuel Cell Science and Technology, vol. 12, no. 1, article 011007, 2015.

[51] S. k. Naimuddin, Development and Electrochemical Characterization of Electrocatalyst Electrodes for Alcoholic by Electrodeposition of $\mathrm{Ni}-\mathrm{Fe}$-Co and Ni-Co on Aluminum, [M.S. thesis], Jadavpur University, Kolkata, India, 2012.

[52] S. Wasmus and A. Küver, "Methanol oxidation and direct methanol fuel cells: a selective review," Journal of Electroanalytical Chemistry, vol. 461, no. 1-2, pp. 14-31, 1999.

[53] S. Hassani, K. Raeissi, and M. A. Golozar, "Effects of saccharin on the electrodeposition of Ni-Co nanocrystalline coatings," Journal of Applied Electrochemistry, vol. 38, no. 5, pp. 689694, 2008.

[54] E. A. Batista, G. R. P. Malpass, A. J. Motheo, and T. Iwasita, "New mechanistic aspects of methanol oxidation," Journal of Electroanalytical Chemistry, vol. 571, no. 2, pp. 273-282, 2004.

[55] C. Lamy, E. M. Belgsir, and J. M. Léger, "Electrocatalytic oxidation of aliphatic alcohols: application to the direct alcohol fuel cell (DAFC)," Journal of Applied Electrochemistry, vol. 31, no. 7, pp. 799-809, 2001.

[56] S. S. Gupta, S. Singh, and J. Datta, "Promoting role of unalloyed Sn in PtSn binary catalysts for ethanol electrooxidation," Materials Chemistry and Physics, vol. 116, no. 1, pp. 223-228, 2009. 
[57] R. Ojani, E. Hasheminejad, and J. B. Raoof, "Direct growth of 3D flower-like Pt nanostructures by a template-free electrochemical route as an efficient electrocatalyst for methanol oxidation reaction," Energy, vol. 90, pp. 1122-1131, 2015.

[58] W. Xu, H. Zhang, G. Li, and Z. Wu, "Nickel-cobalt bimetallic anode catalysts for direct urea fuel cell," Scientific Reports, vol. 4, no. 1, article 5863, 2015. 


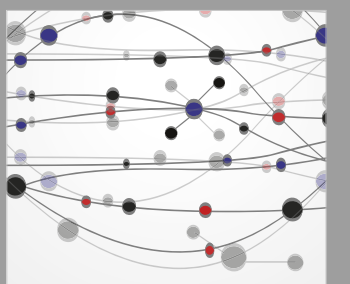

The Scientific World Journal
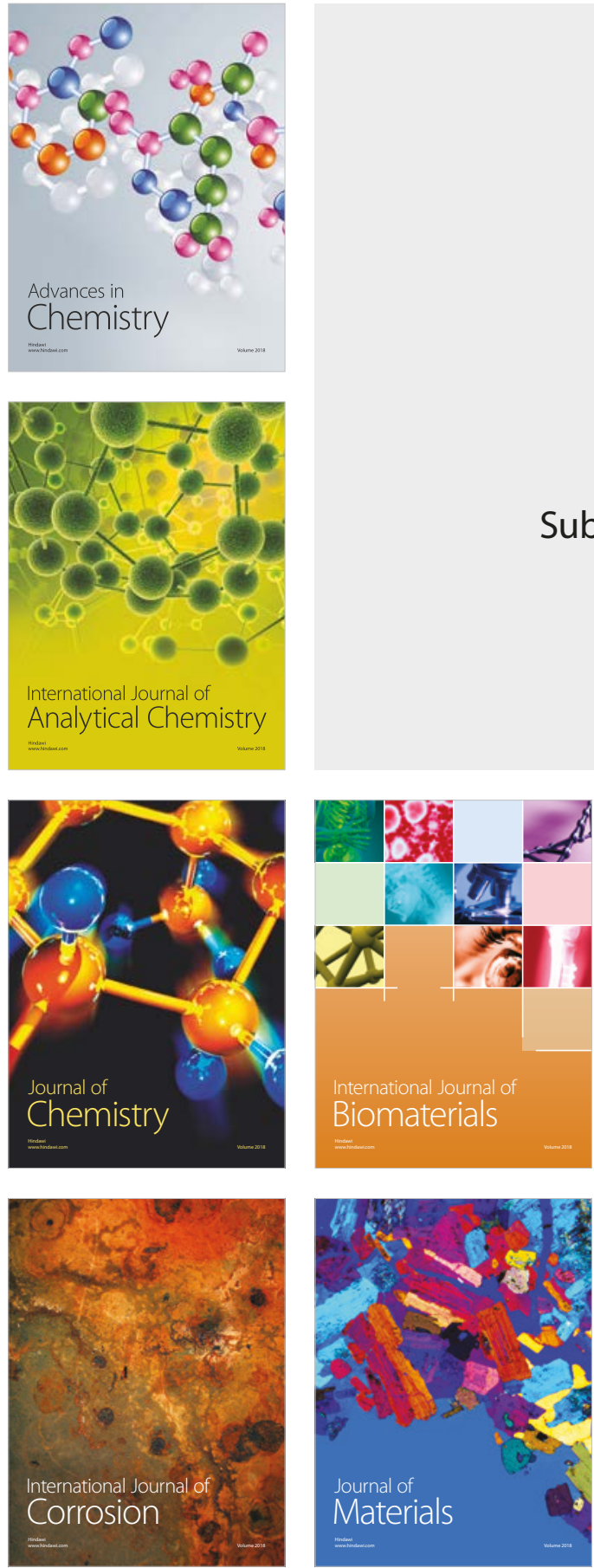

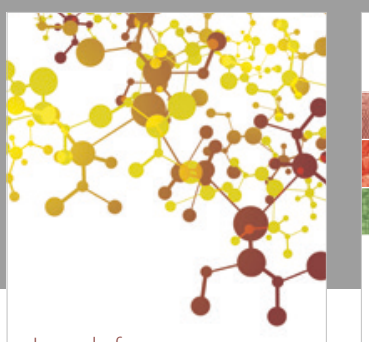

Journal of

Applied Chemistry
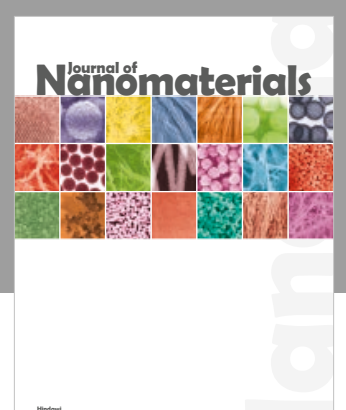

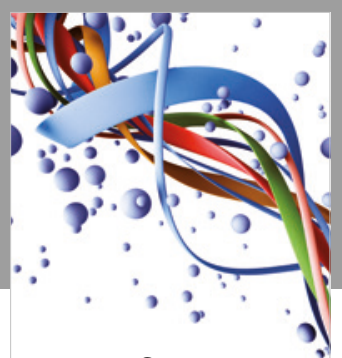

Scientifica

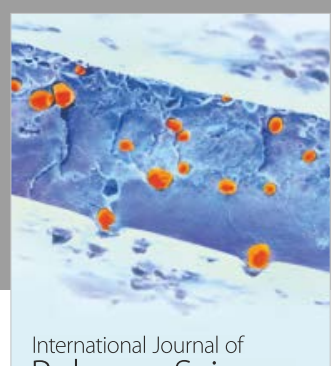

Polymer Science

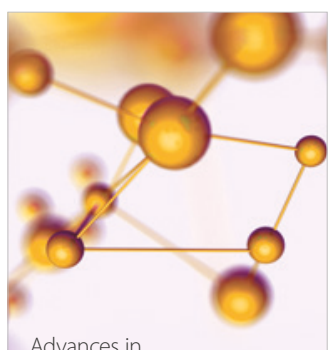

Physical Chemistry
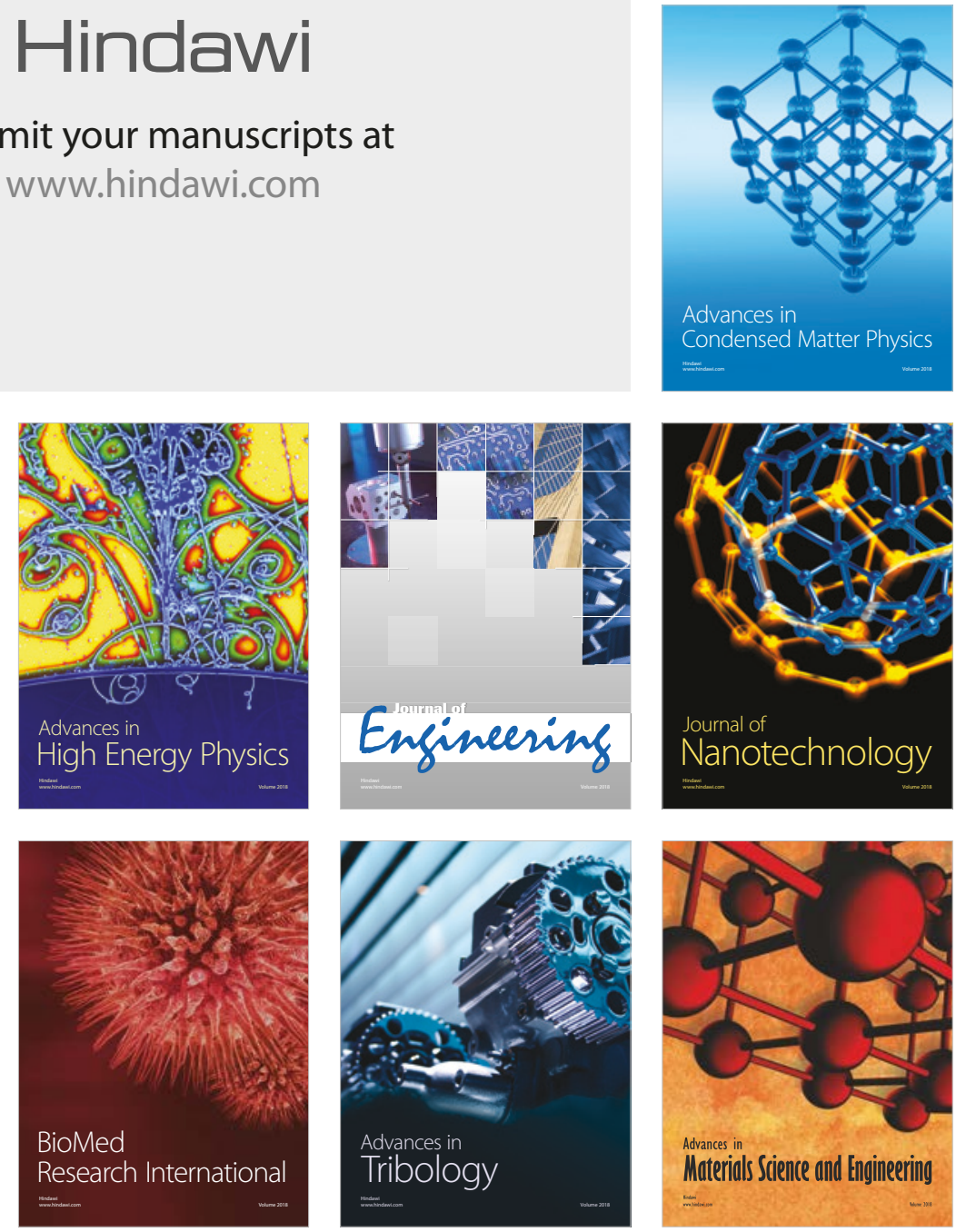